\title{
PENGARUH MODEL PROBLEM BASED LEARNING TERHADAP KETERAMPILAN PROSES SAINS PADA MATERI SISTEM PERNAPASAN DI KELAS XI SMA PGRI PRABUMULIH
}

\author{
Munir $^{1}$, Erie Agusta ${ }^{2}$, Beby Desty Arisandy ${ }^{3 *}$ \\ ${ }^{1}$ Fakultas Ilmu Tarbiyah dan Keguruan, UIN Raden Fatah Palembang, JL. Prof. K.H Zainal Abidin Fikri No.IA \\ KM 3,5, Palembang 30126, Indonesia \\ ${ }^{2}$ Fakultas Keguruan dan Ilmu Pendidikan, UM Palembang, JL. Ahmad Yani Plaju, Palembang 30126, \\ Indonesia \\ ${ }^{3}$ Prodi Pendidikan Biologi, Fakultas Ilmu Tarbiyah dan Keguruan, UIN Raden Fatah Palembang, JL. Prof. K.H \\ Zainal Abidin Fikri No.IA KM 3,5, Palembang 30126, Indonesia \\ *email: bebydesty21@gmail.com \\ Telp: +628-5377-096606
}

\begin{abstract}
This study is based on the low level of students' science process skills. This is because in the learning process that takes place students are more passive role and only receive learning materials provided by the teacher. Model Problem Based Learning is a learning model that is using the problem as a benchmark, the purpose of this study was to determine the effect of the Model Problem Based Learning (PBL) on Science process skills To the material of the respiratory system in the class XI on SMA PGRI Prabumulih. This research uses quasi-experimental research (Quasi Experimental Reasearch) using descriptive quantitative data analysis techniques. The instrument used in this research is the test and performance assessment. Analysis of the data from the two classes using t-test Independen Sampel t test Analysis of the data from the two classes using t-test with independent testing samples test-t with $t$ count $>t$ table $(2,066>2,000)$, then $\mathrm{H} 0$ rejected and $\mathrm{H}$ a accepted, which means that the model of problem based learning affects the students' science process skills, and Paired sample t-test in experimental class with the value $t$ count $<\mathrm{t}$ table $(-6.353<-2.045)$, then Ho is rejected it means there is a difference science process skills between before and after the implementation of the learning model of problem-based learning. It was concluded that model of problem based learning It was concluded that model of problem based learning affects on the material respiratory system science process skills of students in class XI SMA PGRI Prabumulih.
\end{abstract}

Keywords: Science Process Skills; Problem Based Learning

\section{PENDAHULUAN}

Pada saat ini pendidikan sudah menjadi suatu kebutuhan primer bagi setiap manusia, termasuk di Indonesia. Hal tersebut disebabkan karena pendidikan memegang peranan penting dalam menciptakan sumber daya manusia (SDM) Indonesia yang berkualitas. Sumber Daya Manusia dibutuhkan untuk membangun negara menjadi negara yang maju dan sejahtera (Novita, 2014).

Pendidikan tidak pernah lepas dari kegiatan belajar, keberhasilan pendidikan sangat dipengaruhi oleh proses belajar mengajar. Belajar merupakan suatu proses yang dilakukan oleh seseorang untuk memperoleh suatu perubahan tingkah laku, hasil pengamatannya sendiri dalam interaksi dengan lingkungan. Salah satu tanda bahwa seseorang telah belajar adalah adanya perubahan tingkah laku pada diri seseorang yang mungkin disebabkan terjadinya perubahan peningkatan keterampilan, pengetahuan, sikap, dan nilai (Anggun, 2012).

Dalam perspektif agama (Islam) belajar merupakan kewajiban dari setiap individu yang beriman untuk memperoleh ilmu pengetahuan sebagai upaya untuk meningkatkan derajat kehidupan mereka. Dalam Al-Qur'an Surat AlMujaadilah ayat 11 dijelaskan (Sakilah, 2013):

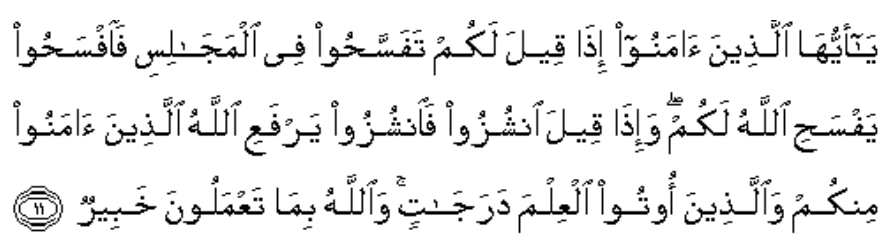


Artinya: Hai orang-orang beriman apabila dikatakan kepadamu: "Berlapang-lapanglah dalam majlis", maka lapangkanlah niscaya Allah akan memberi kelapangan untukmu. Dan apabila dikatakan: "Berdirilah kamu", maka berdirilah, niscaya Allah akan meninggikan orang-orang yang beriman di antaramu dan orang-orang yang diberi ilmu pengetahuan beberapa derajat. Dan Allah Maha Mengetahui apa yang kamu kerjakan.

Al-Ghazali mengungkapkan bahwa mencari ilmu atau mengajarkannya adalah bagian dari ibadah kepada Allah. Oleh karena itu hendaknya proses pendidikan didasari pada tujuan untuk mendekatkan diri kepada Allah dan untuk mendapatkan kebahagiaan dunia dan akhirat. Seorang guru yang mengajar secara tulus ikhlas, hanya mengharap ridha dari Allah, maka ia dianggap sebagai khalifah Allah, dan Allah akan memberikan keistimewaan tersendiri baginya (Munir, 2010).

Pendidikan IPA adalah salah satu aspek pendidikan yang menggunakan IPA sebagai salah satu alat mencapai tujuan pendidikan, khususnya tujuan pendidikan IPA. IPA berkaitan dengan cara mencari tahu tentang alam secara sistematis, sehingga IPA bukan hanya penguasaan kumpulan pengetahuan yang berupa fakta-fakta, konsep-konsep, atau prinsipprinsip saja tetapi juga merupakan suatu proses penemuan (Ali dkk, 2013). Menurut Novitasari (2012), mata pelajaran biologi merupakan salah satu bidang pada mata pelajaran Ilmu Pengetahuan Alam (IPA) atau sains yang dikembangkan melalui kemamapuan berfikir analitis, induktif, dan deduktif.

Berdasarkan Permendikbud No. 65 tahun 2013 tentang standar proses menyebutkan bahwa sasaran pembelajaran mencakup pengembangan ranah keterampilan, pengetahuan dan sikap. Biologi sebagai sains mengedepankan ketiga aspek minds on, hands on dan hearts on yaitu kemampuan menggunakan pikiran untuk membangun konsep melalui pengalaman langsung yang disertai dengan sikap ilmiah.

Dengan mempelajari biologi siswa diharapakan dapat memiliki pengalaman langsung terhadap lingkungan sekitar sebagai sumber pembelajaran, dapat mencari tahu dan memahami alam secara sistematis, membuat siswa dapat menemukan hal-hal baru dalam kehidupan pada kenyataan yang ada di alam, memiliki kemampuan untuk memecahkan masalah dan meningkatkan keterampilan proses sain

Sayangnya kenyataan ini tidak sesuai dengan realita yang ada, berdasarkan hasil data awal pada dua kelas yang diteliti, maka diperoleh informasi bahwa kelas XII.IA. 1 memiliki nilai rata-rata kelas 47,04 dengan presentasi siswa tuntas sebanyak $19 \%$, dan kelas XII.IA. 2 memiliki nilai rata-rata kelas 45 dengan presentasi siswa tuntas sebanyak $11 \%$. Pengujian data awal ini menggunakan Indikator keterampilan proses sains anatara lain: menyusun hipotesis, memprediksi, mengkomunikasikan, menginterpretasikan dan menyimpulkan dengan tujuan mengukur keterampilan proses siswa pada SMA PGRI Prabumulih. Berdasarkan data awal yang diperoleh, diketahui bahwa keterampilan proses sains siswa dapat dikatakan rendah.

Hal tersebut dikarenakan pada proses pembelajaran yang berlangsung siswa IPA di SMA PGRI Prabumulih lebih berperan pasif dan hanya menerima materi pembelajaran yang diberikan oleh guru. Pada proses pembelajaran yang demikian siswa memiliki keterbatasan dalam pemahaman konsep, dimana pemahaman tersebut hanya terbatas pada materi yang diberikan guru. Menurut Novita (2014), pada praktiknya di lapangan, proses pembelajaran yang dilaksanakan cenderung lebih kepada suasana belajar dengan komunikasi satu arah (teacher center), proses pembelajaran tersebut sudah tidak cocok lagi diterapkan di tengah ledakan informasi ilmu pengetahuan dan teknologi seperti sekarang ini. Keaktifan siswa dalam proses pembelajaran dibutuhkan untuk memberikan pengalaman langsung dalam proses pembelajaran dan memberikan kesempatan pada siswa untuk lebih banyak menambah wawasan yang berkaitan dengan materi pembelajaran serta mengembangkan pemahaman konsep. Menurut Rusnayati dan Prima (2015), pada proses pembelajaran siswa hanya berperan sebagai penerima materi pelajaran. Padahal seharusnya siswa turut serta mengembangkan keterampilan proses yang dimilikinya sehingga mampu meningkatkan penguasaan konsep mengenai pokok bahasan yang sedang dipelajari melalui masalah.

Salah satu model pembelajaran yang melibatkan keaktifan siswa adalah dengan model problem based learning (PBL). Problem Based Learning adalah suatu pendekatan pembelajaran yang menggunakan masalah sebagai titik tolak pembelajaran dan untuk dapat menyelesaikan suatu masalah peserta didik memerlukan pengetahuan baru untuk dapat menyelesaikannya. Dalam memecahkan masalah, problem based learning lebih mengutamakan keaktifan siswa karena kegiatan dalam problem based learning meliputi pengamatan terhadap masalah, perumusan terhadap hipotesis, perencanaan penelitian sampai pelaksanaannya, hingga mendapatkan sebuah kesimpulan dari jawaban atas 
permasalahan yang diberikan (Rusnayati dan Prima, 2011).

Sintak atau langkah-langkah pembelajaran dalam problem based learning menurut Arends (2012), antara lain:1) memberikan orientasi suatu masalah pada peserta didik (orient student to the problem), 2) mengorganisasikan peseta didik untuk meneliti (organize student for study), 3): mendampingi penyelidikan mandiri dan kelompok, 4): mengembangkan dan mempresentasi hasil (develop and present article and exhibits) , 5) analisis dan evaluasi dari pemecahan masalah (analyze and evaluate the problem-solving process).

Pada sekolah SMA PGRI Prabumulih model pembelajaran problem based learning ini sebelumnya belum pernah digunakan, guru IPA pada sekolah ini lebih banyak menggunakan metode pembelajaran yang bersifat satu arah dimana guru yang memberikan materi pembelajaran kepada siswa dan siswa hanya beperan pasif sebagai penerima materi.

Selain dari proses pembelajaran yang berlangsung satu arah, penyampaian materi yang dilakukan oleh guru tidak dilengkapi dengan media pembelajaran, dalam proses pembelajaran yang berlangsung siswa hanya menggunakan buku biologi yang disediakan pihak sekolah dan LKS. Media pembelajaran ini dibutuhkan untuk membantu memberikan gambaran kepada siswa berkaitan dengan materi pembelajaran yang disampaikan oleh guru. Kemudian guru belum menerapkan eksperimen pada materi sistem pernapasan, hal ini juga membuat siswa belum terbiasa untuk melakukan eksperimen berkaitan dengan keterampilan proses sains pada siswa di SMA PGRI Prabumulih.

Guru lebih mementingkan hasil belajar khususnya dari segi ranah kognitif daripada proses pembelajaran yang dialami siswanya. Guru beranggapan bahwa semakin banyak siswa yang memperoleh hasil belajar yang tinggi, maka guru dapat dikatakan telah berhasil dalam melaksanakan kegiatan pembelajaran. Akan tetapi, sering kali guru tidak menyadari bahwa keberhasilan pembelajaran tidak hanya dilihat dari hasil yang dicapai oleh siswa, tetapi juga dari segi prosesnya. Dengan kata lain, optimalnya hasil belajar siswa ditentukan pula oleh proses belajar yang dialami siswa. Oleh sebab itu, perlu dilakukan penilaian terhadap proses belajar mereka (Novita, 2014).

Salah satu gambaran mengenai masih dikesampingkannya penilaian proses dalam pembelajaran adalah diabaikannya pengembangan keterampilan proses sains. Pada dasarnya sains bukan hanya merupakan pengetahuan mengenai fakta-fakta atau konsep-konsep, tetapi juga merupakan suatu cara kerja, cara berpikir, dan cara memecahkan masalah. Guru tidak memahami hakikat tersebut sehingga sering kali hanya memberikan teori kepada siswa tanpa mempraktekannya secara langsung. Cara tersebut menyebabkan siswa tidak memiliki kesempatan untuk mengetahui bagaimana teori tersebut ada dan digunakan dalam kehidupan nyata. Selain itu siswa juga tidak mendapat ruang untuk melatih keterampilan proses sainsnya (Novita, 2014).

Keterampilan proses sains merupakan keterampilan yang melibatkan segenap kemampuan siswa dalam memperoleh pengetahuan berdasarkan fenomena. Kemampuan siswa yang dimaksud adalah keterampilan mengamati, mengelompokkan, menafsirkan, memprediksi, mengajukan pertanyaan, berhipotesis, merencanakan percobaan, menggunakan alat dan bahan, menerapkan konsep, berkomunikasi dan melaksanakan percobaan. Keterampilan proses sains penting dalam pembelajaran saat ini karena, perkembangan ilmu pengetahuan dan teknologi berlangsung semakin cepat sehingga tidak mungkin lagi guru mengajarkan semua konsep dan fakta pada siswa, adanya kecenderungan bahwa siswa lebih memahami konsep-konsep yang rumit dan abstrak jika disertai dengan contoh yang konkret, penemuan dan perkembangan ilmu pengetahuan dan teknologi tidak bersifat mutlak, tapi bersifat relatif, dalam proses belajar mengajar, pengembangan konsep tidak terlepas dari pengembangan sikap dan nilai dalam diri anak didik (Wahyudi $d k k, 2015$ ).

Berdasarkan latar belakang yang di uraian di atas, maka akan dilakukan penelitian dengan judul "Pengaruh Model Problem Based Learning (PBL) terhadap Peningkatan Keterampilan Proses Sains pada Materi Sistem Pernapasan kelas XI di SMA PGRI Prabumulih Tahun Ajar 2016/2017.”

\section{METODOLOGI PENELITIAN}

Penelitian ini dilaksanakan pada 8 Mei 2017 sampai 25 Mei 2017 di SMA PGRI Prabumulih Tahun Akademik 2016/2017. Penelitian ini menggunakan jenis penelitian eksperimen semu (Quasi Eksperimental Research) dengan desain Nonequivalent Control Grup Design. Pengambilan sampel pada penelitian ini menggunakan teknik sampling jenuh, dikarenakan semua sampel pada penelitian ini merupakan populasi. Variabel bebas dalam penelitian ini adalah model pembelajaran Problem Based Learning (PBL) yang diterapkan pada kelompok eksperimen dan model pembelajaran konvensional yang diterapkan pada kelompok kontrol 
sedangkan variabel terikat dalam penelitian ini adalah keterampilan proses sains.

Metode pengumpulan data dilakukan dengan tes, penilaian kinerja, dan dokumentasi. Bentuk tes yang digunakan berupa soal-soal pre-test dan post-test keterampilan proses sains, dan lembar penilaian kinerja. Data penelitian keterampilan proses sains dari pre-test dan post-test dianalisis secara statistik parametrik yaitu dihitung dengan $t$-test, sedangkan penilaian kinerja dianalisis secara deskriptif.

\section{HASIL DAN PEMBAHASAN}

\section{A. Hasil}

Hasil Pre-test Keterampilan Proses Sains Kelas Kontrol dan Eksperimen

Berdasarkan hasil pre-test pada kelas eksperimen dan kelas kontrol, dapat diketahui bilai rata-rata pre-test eksperimen adalah 49,19 dan kelas kontrol adalag 51,56. Hal ini menunjukkan bahwa nilai rata-rata pre-test kelas eksperimen lebih rendah dibandingkan dengan nilai rata-rata pre-test kelas kontrol. Selisih nilai pre-test antara kedua kelas tersebut adalah sebesar 2,37. Nilai rerata 51,56 lebih tinggi dibandingkan dengan 49,19 sehingga kelas XI IPA 2 yang dipilih sebagai kelas kontrol dan XI IPA 1 sebagai kelas eksperimen.

Persentase keterampilan proses sains tertinggi dari masing-masing kelas eksperimen dan kelas eksperimen pada indikator mengkomunikasikan dengan nilai masingmasing secara berurutan, yaitu $60 \%$ pada kelas eksperimen dan 68\% pada kelas kontrol. Dan persentase keterampilan proses sains terendah terdapat pada indpikator menerapkan konsep dengan nilai masing-masing secara berurutan, yaitu $23 \%$ pada kelas eksperimen dan $25 \%$ pada kelas kontrol. Hasil persentase pre-test keterampilan proses sains pada kelas eksperimen dan kelas kontrol dapat dilihat pada tabel berikut:

Tabel 1. Persentase Ketercapaian Keterampilan Proses Sains Kelas Eksperimen dan Kelas Kontrol

\begin{tabular}{ccccc}
\hline Indikator KPS & $\begin{array}{c}\text { Persentase kelas } \\
\text { Esperimen }\end{array}$ & Kategori & $\begin{array}{c}\text { Persentase } \\
\text { kelas } \\
\text { Kontrol }\end{array}$ & Kategori \\
\hline Inter Pretasi & $46 \%$ & Cukup Baik & $45 \%$ & Cukup Baik \\
Menyimpulkan & $49 \%$ & Cukup Baik & $56 \%$ & Cukup Baik \\
Hipotesis & $45 \%$ & Cukup Baik & $54 \%$ & Cukup Baik \\
Prediksi & $47 \%$ & Cukup Baik & $56 \%$ & Cukup Baik \\
Komunikasi & $62 \%$ & Cukup Baik & $68 \%$ & Baik \\
Merencanakan Percobaan & $48 \%$ & Cukup Baik & $45 \%$ & Cukup Baik \\
Observasi & $42 \%$ & Kurang Baik & $44 \%$ & Cukup Baik \\
Menerapkan konsep & $26 \%$ & Kurang Baik & $28 \%$ & Kurangbaik \\
\hline
\end{tabular}

\section{Hasil Post-test Keterampilan Proses Sains Kelas Kontrol dan Eksperimen}

Nilai rata-rata pada kelas eksperimen maupun kelas kontrol mengalami perrubahan dengan nilai 69,67 pada kelas eksperimen dan 65,48 pada kelas kontrol jumlah ini meningkat dari nilai sebelumnya pada pre-test sebelumnya. Hasil persentase post-test keterampilan proses sains pada kelas eksperimen dan kelas kontrol menunjukan bahwa terdapat perbedaan yang cukup signifikan dari hasil post-test kelas kontrol dan kelas eksperimen. Rata-rata kelas eksperimen dan kontrol menunjukkan perbedaan yang signifikan masing-masing, yaitu $71 \%$ dan $67 \%$ dengan kategori baik. Persentase keterampilan proses sains tertinggi dari kelas kontrol dan eksperimen adalah pada indikator mengkomunikasikan dimana kelas eksperimen memperoleh sebanyak $82 \%$ sedangkan kelas kontrol memperoleh $79 \%$ dengan kategori masuing-masing sangat baik pada kelas eksperimen dan baik pada kelas kontrol. Dan persentase keterampilan proses sains terendah terdapat pada indikator menerapkan konsep dengan nilai masing-masing secara berurutan, yaitu $65 \%$ pada kelas eksperimen dan $47 \%$ pada kelas kontrol.

Hasil persentase post-test keterampilan proses sains pada kelas eksperimen dan kelas kontrol dapat dilihat pada tabel berikut: 
Tabel. 2 Persentase Ketercapian Keterampilan Proses Sains Kelas Eksperimen dan Kelas Kontrol

\begin{tabular}{ccccc}
\hline Indikator KPS & $\begin{array}{c}\text { Persentase kelas } \\
\text { Esperimen }\end{array}$ & Kategori & $\begin{array}{c}\text { Persentase kelas } \\
\text { Kontrol }\end{array}$ & Kategori \\
\hline Inter Pretasi & $66 \%$ & Baik & $59 \%$ & Cukup baik \\
Menyimpulkan & $69 \%$ & Baik & $66 \%$ & Baik \\
Hipotesis & $77 \%$ & Baik & $58 \%$ & Cukup Baik \\
Prediksi & $73 \%$ & Baik & $77 \%$ & Baik \\
Komunikasi & $82 \%$ & Sangat Baik & $79 \%$ & Baik \\
Merencanakan Percobaan & $65 \%$ & Baik & $56 \%$ & Baik \\
Observasi & $77 \%$ & Baik & $63 \%$ & Baik \\
Menerapkan konsep & $65 \%$ & Baik & $47 \%$ & Cukup Baik \\
\hline
\end{tabular}

\section{Hasil Penilaian Kinerja}

Pada penelitian ini digunakan penilaian kinerja untuk menilai keterampilan proses sains siswa yang berkaitan dengan kegiatan siswa dalam kegiatan praktikum.Data tersebut disajikan pada tabel berikut

Tabel 3 Hasil Penilaian Kinerja terhadap Keterampilan Prose Sains Siswa Kelas Eksperimen dan Kontrol Indikator KPS Kelas Eksperimen Kelas Kontrol

\begin{tabular}{|c|c|c|c|c|}
\hline & Persentase & Kategori & Persentase & Kategori \\
\hline Hipotesis & $70 \%$ & Baik & $62 \%$ & Baik \\
\hline Merencanakan Percobaan & $68 \%$ & Baik & $59 \%$ & Cukup Baik \\
\hline Observasi & $69 \%$ & Baik & $60 \%$ & Cukup Baik \\
\hline Prediksi & $68 \%$ & Baik & $61 \%$ & Baik \\
\hline Menerapkan Konsep & $68 \%$ & Baik & $62 \%$ & Baik \\
\hline Komunikasi & $70 \%$ & Baik & $62 \%$ & Baik \\
\hline Interpretasi & $68 \%$ & Baik & $61 \%$ & Baik \\
\hline Kesimpulan & $69 \%$ & Baik & $61 \%$ & Baik \\
\hline
\end{tabular}

Berdasarkan data di atas dapat diketahui bahwa persentase keterampilan proses sains siswa pada kelas eksperimen, tampak bahwa indikator tersebut secara keseluruhan memiliki kategori baik. Sedangkan pada kelas kontrol indikator keterampilan proses sains yang meliputi merencanakan percobaan dan observasi berkategori cukup baik sedangkan indikator menyusun hipotesis, prediksi, menerapkan konsep, komunikasi, interpretasi dan kesimpulan masuk dalam kategori baik.

\section{B. Pembahasan}

Pada penelitian ini digunakan uji hipotesis, yaitu uji independen sampel t-test terdapat perbedaan keterampilan proses sains pada kelas eksperimen dan kontrol hal ini dibuktikan dengan nilai signifikan yang yang lebih kecil dari 0,05 $(0,044<0,05)$ yang artinya Ho ditolak (dapat dilihat pada lampiran 19).

Berdasarkan analisis perhitungan, rerata hasil tes keterampilan proses sains siswa yang mengikuti pembelajaran menggunakan model pembelajaran problem based learning pada kelas eksperimen dan model konvensional pada kelas kontrol diperoleh perbedaan yang signifikan pada nilai rerata post-test kelas eksperimen dan kelas kontrol. Nilai rerata post-test kelas eksperimen dan kelas kontrol sebear 69,68, selisih nilai keduanya sebesar 4,21 secara umum menggambarkan kemampuan penguasaan keterampilan proses sains siswa kelas eksperimen lebih tinggi daripada siswa kelas kontrol yang menggunakan model konvensional. Selain itu, penggunaan problem based learning dapat meningatkan nilai pada kelas eksperimen yang mula-mula memiliki nilai rata-rata dibawah kelas kontrol, setelah di terapkannya model pembelajaran problem based learning nilai kelas eksperimen meningkat dari rata-rata 49,19 menjadi 69,68 ini meningkat sebesar 20,49, sedangkan kelas kontrol memiliki rerata dari sebesar 13,91 meningkat dengan nilai 51,56 menjadi 65,57 . Jadi, dapat disimpulkan bahwa menggunakan model pembelajaran problem based learning berpengaruh terhadap keterampilan proses sains pada materi sistem pernapasan pada kelas XI SMA PGRI Prabumulih. 
Hal ini sejalan dengan penelitian Wahyudi (2015), problem based learning dapat membuat siswa berfikir kritis atau berfikir tingkat tinggi. Problem based learning dapat memperngaruhi pengetahuan yang didapatkan siswa mencapai kemampuan metakognisis dan membuat siswa berfikir tingkat tinggi sehingga keterampilan proses sains dapat dikuasai siswa dengan kata lain pengetahuan dan keterampilan proses sains dapat meningkat.

Problem based learning, memiliki beberapa tahapan, antara lain: Tahapan pertama (Orient student to the problem) memberikan orientasi suatu masalah kepada siswa, model pembelajaran problem based learning lebih menitik beratkan pada permasalahanpermasalahan yang sering terjadi dilingkungan siswa. Permasalahan yang terjadi dalam kehidupan sehari-hari siswa yang bersifat kontekstual menjadikan siswa terlatih untuk merumuskan permasalahan dan menyelesaikan masalah. Hal ini berarti, siswa belajar mengembangkan keterampilan proses sains. Pada tahapan ini guru memberikan orientasi masalah dengan mengajukkan pertanyaan kepada siswa. Pendapat ini didukung oleh pendapat Wahyudi (2015), dalam memecahkan masalah, problem based learning lebih mengutamakan keaktifan siswa karena kegiatan dalam problem based learning meliputi pengamatan terhadap masalah, perumusan terhadap hipotesis, perencaaan penelitian sampai pelaksanaannya, hingga mendapatkan sebuah kesimpulan dari jawaban atas permasalahan yang diberikan.

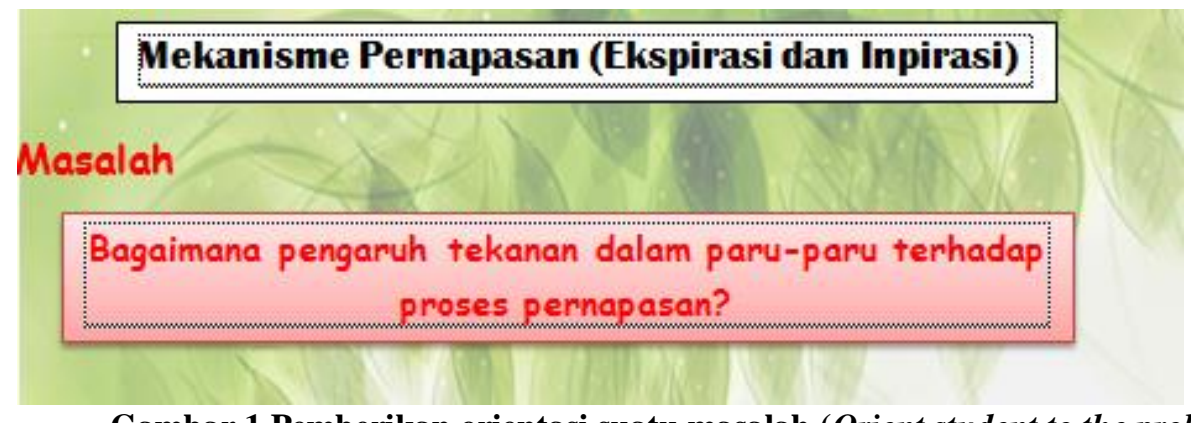

Gambar 1 Pemberikan orientasi suatu masalah (Orient student to the problem) (Sumber: Doc, Pribadi, 2017)

Pengamatan terhadap masalah, perumusan terhadap hipotesis, perencanaan penelitian sampai pelaksanaannya, hingga mendapatkan kesimpulan, hal ini berkaitan dengan indikator yang terdapat pada keterampilan proses sains sehingga siswa dapat mengembangkan keterampilan proses sains berkaitan dengan pemecahan masalah. Lidnillah (2014), menyatakan dalam sala satu kekurangan problem based learning lebih cocok untuk pembelajaran yang menuntut kemampuan tertentu yang berkaitan dengan pemecahan masalah.

Selanjutnya langkah-langkah model pembelajaran problem based learning membantu siswa melakukan metode ilmiah yang di dalamnya terdapat keterampilan proses sains. Jika ditinjau pada langkah yang pertama, yaitu orientasi masalah, siswa belajar tentang bagaimana permasalahan tesebut terjadi, apa yang menyebabkan permasalahan tersebut terjadi dan siapa yang terlibat dalam permasalahan tersebut. Menurut Sani (2014), Permasalahan nyata yang dikaji dengan menerapkan problem based learning diharapkan dapat membuat siswa mengajukan pertanyaan, mengaktifkan pengetahuan awal, menguji pemahaman siswa, mengelaborasi pengetahuan baru, memperkuat pemahaman siswa, memberikan motivasi untuk belajar dan membuat siswa melatih logika, dan pendekatan analitis terhadap situasi yang tidak dikenal. Pemilihan dan perumusan permasalahan yang tepat akan dapat memotivasi siswa untuk belajar aktif mengembangkan pengetahuan secara mandiri dan berkelompok.

Langkah yang kedua, yaitu mengorganisasikan siswa untuk belajar (organize student for study). Pada tahapan ini, siswa mencari informasi dari berbagai sumber terkait dengan permasalahan yang sedang diselidiki. Pada tahapan ini, siswa menginvestigasi masalah yang diberikan oleh guru dengan berbagai sumber, sehingga dengan informasi yang didapatkan siswa dapat memberikan dugaan sementara atau hipotesis. Menurut Hilpan (2014), hipotesis adalah suatu perkiraan yang beralasan untuk menerangkan suatu kejadian atau pengalaman tertentu. Keterampilan berhipotesis merupakan keterampilan merumuskan merumuskan teori atau 
pendapat yang dianggap benar yang kebenarannya masih harus dibuktikan.

Dari hasil post-test yang dilakukan pada kelas eksperimen dan kelas kontrol didapatkan hasil pada indikator menyusun hipotesis $77 \%$ dengan kategori baik pada kelas eksperimen dan sedangkan pada kelas kontrol di dapatkan hasil $58 \%$ dengan kategori baik, kemudian pada penilaian kinerja diketahui pada kelas eksperimen $70 \%$ dengan kategori baik sedangkan pada kelas kontrol 60\% dengan kategori cukup. Dari data tersebut diketahui kelas eksperimen lebih baik penyusunan hipotesisnya dibandingkan dengan kelas kontrol, hal ini dipengaruhi oleh kegiatan pembelajaran pada kelas eksperimen siswa menginvestigasi masalah yang diberikan oleh guru dengan berbagai sumber, sehingga dengan informasi yang didapatkan siswa dapat memberikan dugaan sementara atau hipotesis sedangkan pada kelas kontrol siswa hanya memperhatikan penjelasan mengenai proses praktikum yang disampaikan oleh guru. Hal ini dapat juga dilihat dari perbedaan hipotesis yang disusun siswa kelas eksperimen dan siswa kelas kontrol, pada kelas eksperimen hipotesis yang disusun oleh siswa dinilai lebih tepat, hal ini karena hipotesis yang disusun siswa dapat menggambarkan kemungkinan yang menyebabkan balon tersebut mengembang dan mengempis secara jelas kemudian hipotesisi yang disusunpun berkaitan dengan pemahaman konsep, berbeda dengan hipotesisi yang disusun siswa pada kelas kontrol, dimana siswa hanya menyebutkan "keluar masuknya udara" hal ini dinilai belum menggambarkan secara jelas dan hipotesis yang disusun juga belum berkaitan dengan pemahaman konsep. Hal tersebut dapat dilihat seperti gambar dibawah ini:

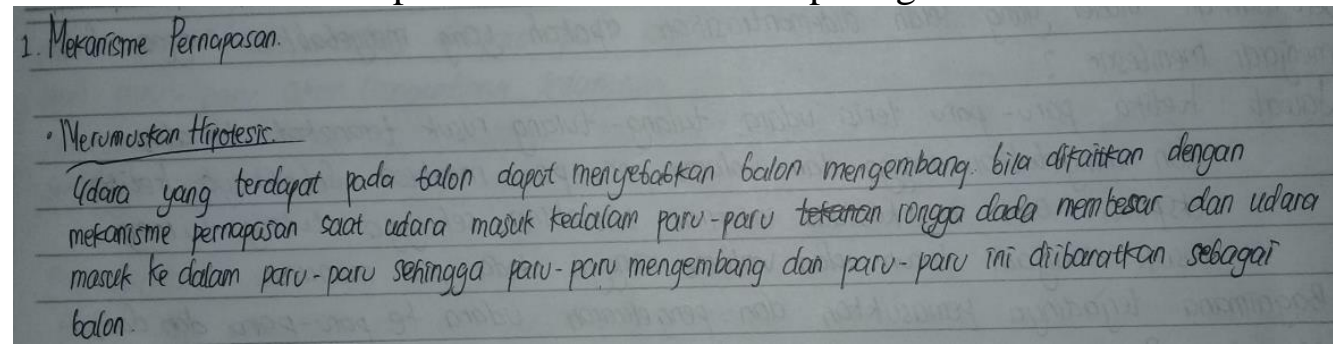

(a)

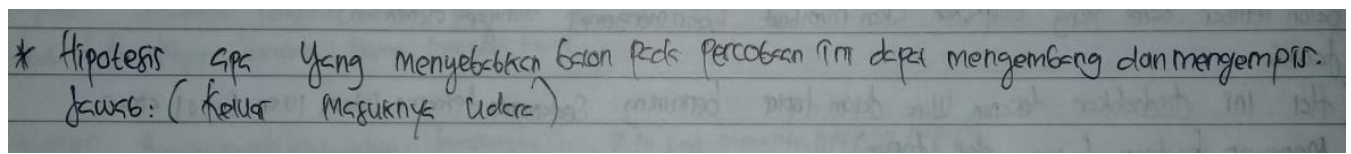

(b)

Gambar 2 Perbedaan penyusunan hipotesis kelas eksperimen dan kelas kontrol, (a) hipotesis siswa pada kelas eksperimen dan (b) hipotesis siswa pada kelas kontrol (Sumber: Dok, Pribadi 2017)

Langkah pembelajaran yang ke tiga, yaitu melakukan penyelidikan mandiri maupun kelompok (assist independent and group investigation). Pada langkah ketiga ini siswa melakukan penyelidikan dengan melakukan eksperimen melalui kegiatan praktikum. Jika dihubungkan dengan aspek keterampilan proses sains, langkah ini sangat erat kaitannya dengan aspek keterampilan proses sains, yakni merencanakan dan melaksanakan percobaan. Setelah siswa dapat merumuskan hipotesis, pada tahapan ini siswa juga merencanakan percobaan yang berkaitan dengan dugaan sementara yang perlu untuk dibuktikan. Menurut Novita (2014), merencanakan sebuah penyelidikan untuk membuktikan hipotesis yang telah dirumuskan sebelumnya dengan bantuan teori dan konsep yang telah dimilikinya. Dengan demikian, siswa dapat termotivasi dan meningkatkan kemampuan intelektualnya.

Dari hasil post-test yang diberikan pada kelas eksperimen dan kelas kontrol didapatkan hasil pada indikator merencanakan percobaan $65 \%$ pada kelas eksperimen dan 59\% pada kelas eksperimen dengan kategori baik pada keduanya Kemudian dari hasil penilaian kinerja didapatkan $68 \%$ dengan kategori baik pada kelas eksperimen dan 59\% dengan kategori cukup baik pada kelas. Pada penilaian kinerja ini, penilaian dilakukan secara langsung oleh observer ketika kegiatan pembelajaran sedangkan post-test penilaian dari uji post-test yang diberikan kepada siswa. Perbedaan antara kelas eksperimen dan kontrol dikarenakan pada tahapan ini kelas eksperimen merencanakan percobaan dengan menyiapkan dan menyusun alat secara langsung. 

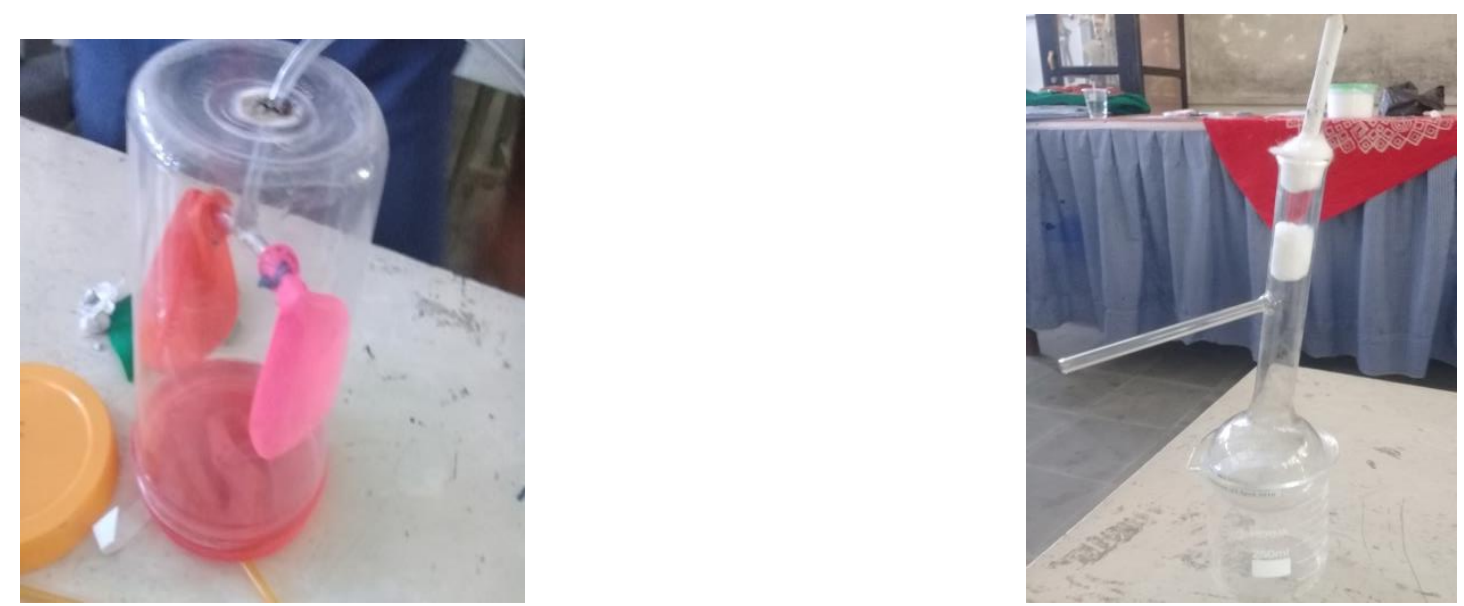

Gambar 2 Alat dan Bahan yang Sudah di Rangkai dalam Praktikum Mekanisme Pernapasan dan Pengaruh Asap Rokok (Sumber: Doc, Pribadi, 2017)

Selain merencanakan percobaan, siswa juga melakukan pengamatan melalui praktikum yang dilakukan yang berkaitan dengan orientasi masalah yang diberikan, pengamatan di sini berkaitan dengan keterampilan proses sains yaitu observasi, pada kegiatan ini siswa melakukan kegiatan percobaan atau obeservasi untuk membuktikan rumusan hipotesis sebelumnya yang berkaitan dengan masalah yang diberikan. Dari kegiatan obeservasi ini siswa dapat memperoleh informasi dan fakta-fakta yang dibutuhkan sehingga siswa dapat memprediksikan, menerapkan konsep, mengkomunikasikan hasil, dan mengambil kesimpulan. Hal ini sesuai dengan pendapat Novita (2014) keterampilan observasi merupakan bagian dari keterampilan proses sains, keterampilan proses sains dapat menjadi titik tumpu untuk pengembangan keterampilan proses sains berikutnya.

Dari hasil post-test yang dilakukan pada kelas eksperimen dan kelas kontrol didapatkan hasil pada indikator observasi $77 \%$ dengan kategori baik pada kelas eksperimen sedangkan pada kelas kontrol didapatkan hasil 63\% dengan kategori baik. Kemudian pada penilaian kinerja diketahui pada kelas eksperimen 69\% dengan kategori baik sedangkan pada kelas kontrol $60 \%$ dengan kategori cukup baik. Penilaian kinerja dilakukan secara langsung oleh observer saat proses pembelajaran berlangsung.

Kemudian selain merencanakan percobaan dan observasi, keterampilan yang dapat terbentuk adalah prediksi, setelah siswa melakukan observasi siswa mendapatkan hasil dari kegiatan praktikum yang dilakukan, siswa dapat menggunakan hasil untuk menentukan prediksi kedepan, contohnya dari hasil praktikum pada frekuensi pernapasan siswa dapat memprediksikan semakin banyak aktifitas yang dilakukan maka frekuensi pernapasan semakin besar. Menurut Hilpan (2014), prediksi adalah memperkirakan berdasarkan data atau kecenderungan hasil pengamatan. Apabila siswa dapat menggunakan pola-pola hasil pengamatan untuk mengemukakan apa yang mungkin terjadi. Dan menerapkan konsep.

Dari hasil post-test yang diberikan pada kelas eksperimen dan kelas kontrol didapatkan hasil pada indikator prediksi $73 \%$ pada kelas eksperimen dan $77 \%$ pada kelas eksperimen dengan kategori baik pada. Kemudian dari hasil penilaian kinerja didapatkan $68 \%$ dengan kategori baik pada kelas eksperimen dan $61 \%$ dengan kategori cukup baik pada kelas kontrol. Pada Indikator prediksi ini siswa diberikan pertanyaan oleh guru berupa "pada kedua percobaan tersebut, lembar karet yang ditarik akan membuat balon mengembang sebaliknya balon lembaran karet yang dilepas akan membuat balon mengempis, mengapa demikian", dari kelas eksperimen dan kelas kontrol siswa dapat membuat prediksi dengan baik pada kedua kelasnya, hal tersebut dapat dilihat pada gambar dibawah ini, dimana siswa dapat menyelaskan penyebab dari mengembang dan mengempisnya balon dan menjelaskan pengaruh dari membran karet terhadap mengambang dan mengempisnya balon. 


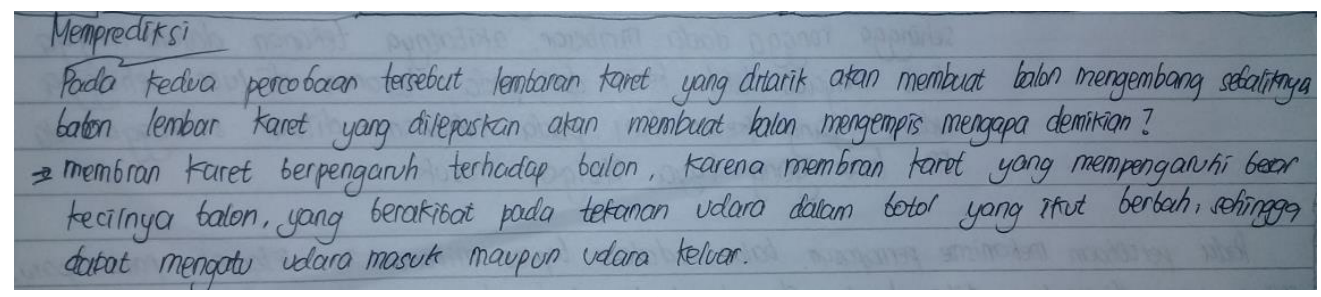

(a)

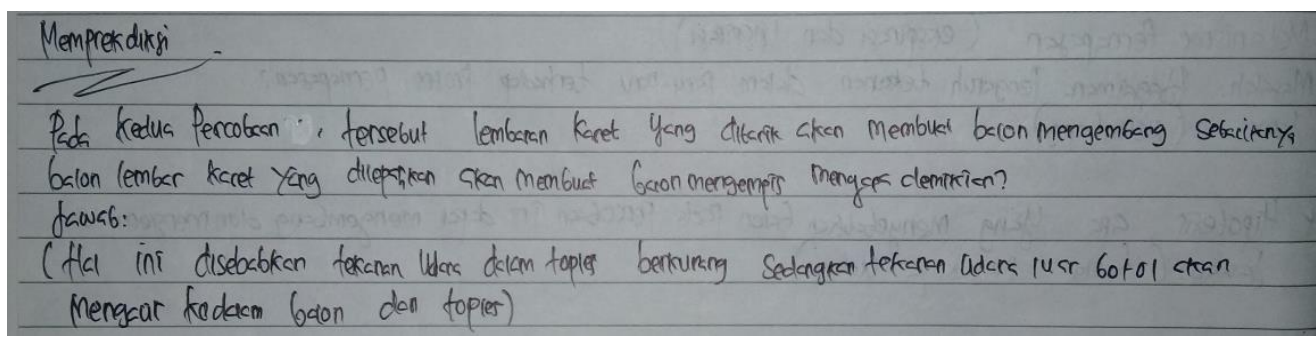

(b)

Gambar 3 Perbedaan prediksi kelas eksperimen dan kelas kontrol, (a) prediksi siswa pada kelas eksperimen dan (b) prediksi siswa pada kelas kontrol

(Sumber: Dok, Pribadi 2017)

Menerapkan konsep pada tahapan ketiga ini pun dapat berkembang, karena siswa telah mendapatkan hasil dari observasi yang dilakukan dan prediksi yang ungkapkan siswa dapat mengaitkan dengan materi yang berkaitan dengan penerapan konsep. Menurut Hilpan (2014), menerapkan konsep meliputi antara lain menjelaskan peristiwa baru dengan menggunakan konsep yang telah dipelajari dalam situasi baru.

Dari hasil post-test yang diberikan pada kelas eksperimen dan kelas kontrol didapatkan hasil indikator menerapkan konsrp $65 \%$ pada kelas eksperimen dengan kategori baik dan $47 \%$ pada kelas kontrol dengan kategori cukup baik. Kemudian dari hasil penilaian kinerja didapatkan $68 \%$ dengan kategori baik pada kelas eksperimen dan $62 \%$ dengan kategori cukup baik pada kelas kontrol. Dari hasil tersebut diketahui persentase keterampilan proses sains lebih besar kelas eksperimen dibandingkan kelas kontrol. Pada hasil laporan siswa dapat dilihat perbedaan penerapan konsep antara kelas eksperimen dan kontrol dari pembahasan yang disampaikan siswa, dari hasil tersebut dapat dilihat pembahasan yang disampaikan siswa kelas eksperimen lebih jelas dan siswa dapat mengaitkan hasil praktikum dengan pemahaman konsep dengan jelas sedangkan lebih banyak penjabaran kemudian penjelasan siswa kelas eksperimen dapat mengaitkan hasil dari kegiatan praktikum dengan baik berebeda dengan kelas kontrol dimana siswa hanya menjelaskan mekanisme pernapasan tanpa mengaitkannya dengan hasil kegiatan praktikum. Hal tersebut dapat dillihat dari gambar dibawah ini:

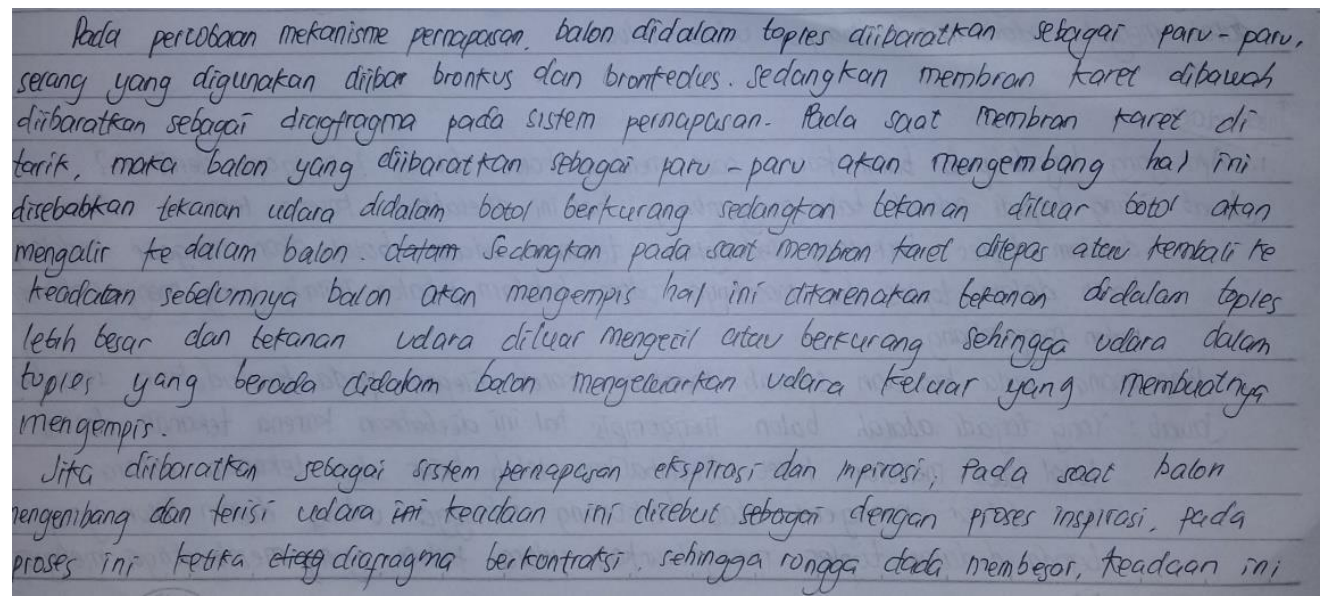




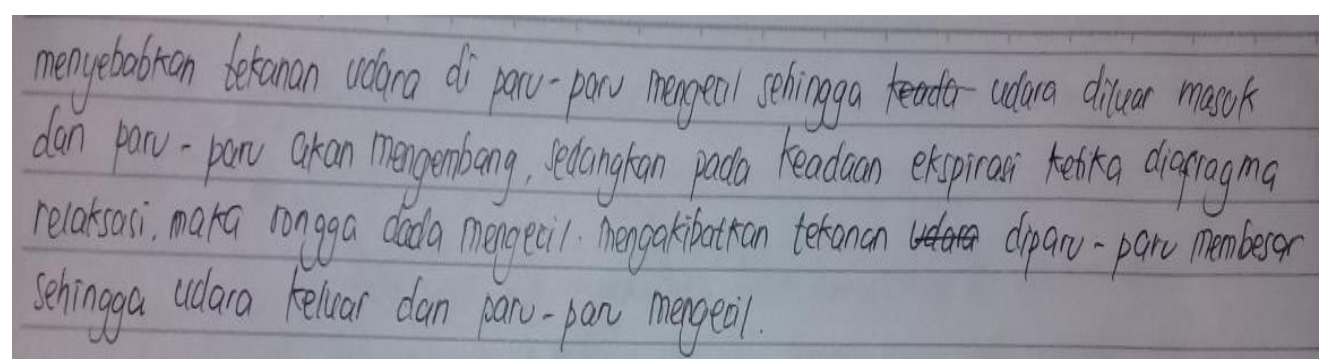

(a)

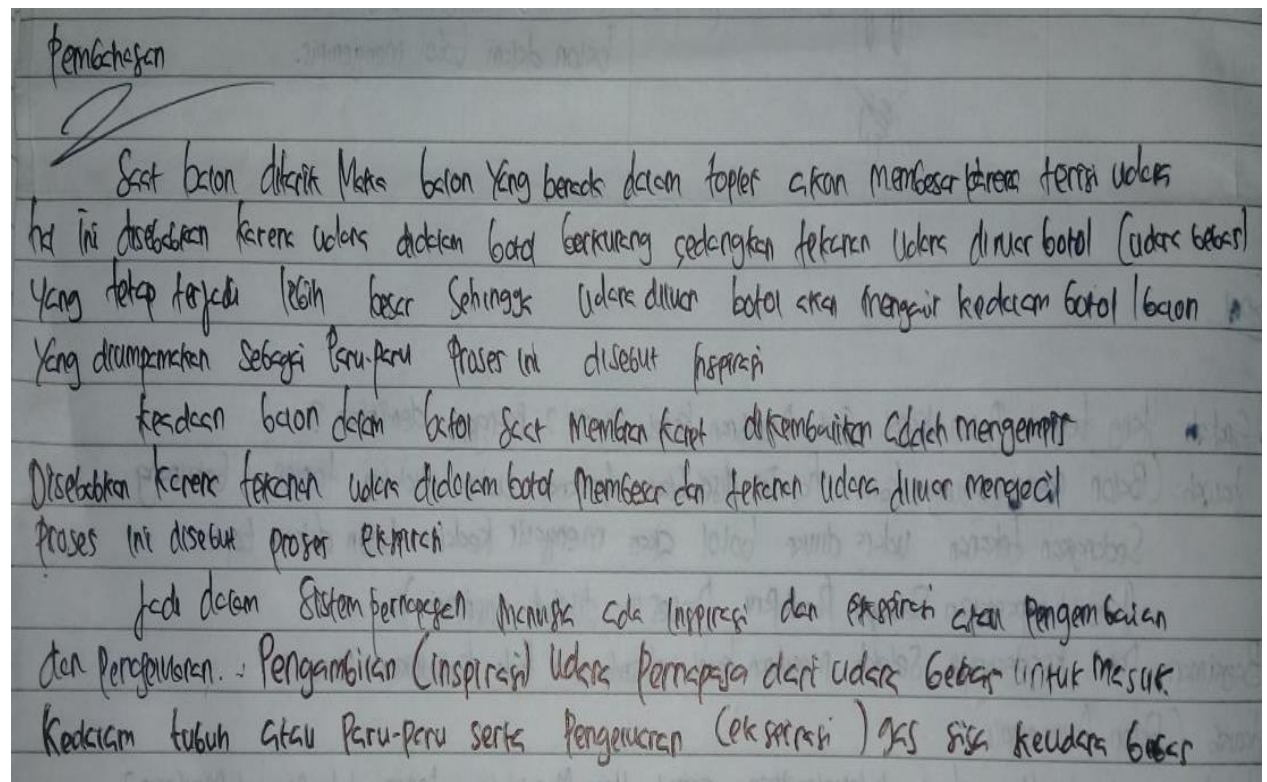

(b)

Gambar 4 Perbedaan pemahaman konsep kelas eksperimen dan kelas kontrol, (a) pemahaman konsep siswa pada kelas eksperimen dan (b) pemahaman konsep siswa pada kelas kontrol

(Sumber: Dok, Pribadi 2017)

Langkah ke empat, yaitu mengembangkan dan menyajikan hasil penelitian (decelop and present article and exhibits). Pada langkah ini siswa siswa melakukan pengembangan hasil penelitian dengan melakukan diskusi pada kelompok masing-masing. Pada tahapan ini siswa melakukan komunikasi pada kelompok masingmasing berdasarkan hasil yang telah didapatkan dari praktikum, para siswa mengolah data hasil dan mendiskusikan hasil kegiatan dengan orientasi permasalahan yang diberikan, sehingga siswa berfikir secara aktif untuk memecahkan masalah yang diberikan. Hal ini sependapat dengan Hilpan (2014), menginformasikan hasil prediksi atau hasil percobaan kepada orang lain termasuk ke dalam keterampilan komunikasi. Bentuk komunikasi ini bisa dalam lisan dan tulisan.

Dari hasil post-test yang diberikan pada kelas eksperimen dan kelas kontrol didapatkan hasil $82 \%$ pada kelas eksperimen dengan kategori sangat baik dan $63 \%$ pada kelas kontrol dengan kategori baik. Kemudian dari hasil penilaian kinerja didapatkan $71 \%$ dengan kategori baik pada kelas eksperimen dan $62 \%$ dengan kategori cukup baik pada kelas kontrol. Dari hasil tersebut diketahui kelas eksperimen memiliki persentrase komunikasi lebih baik dibandingkan dengan kelas kontrol. Karena pada tahapan ini siswa memiliki kesempatan untuk berkomunikasi dan diskusi secara baik pada kelas eksperimen sendangkan pada kelas kontrol siswa hanya memperharikan guru. Dibawah ini merupakan gambar perbedaan hasil lembar siswa kelas eksperimen dan kelas kontrol, pada hasil tersebut siswa kelas eksperimen bisa memberikan kerangan dengan jelas dan mengaitkan dengan konsep, sedangkan kelas kontrol hanya menjelaskan keterangan dari apa yang terjadi. 


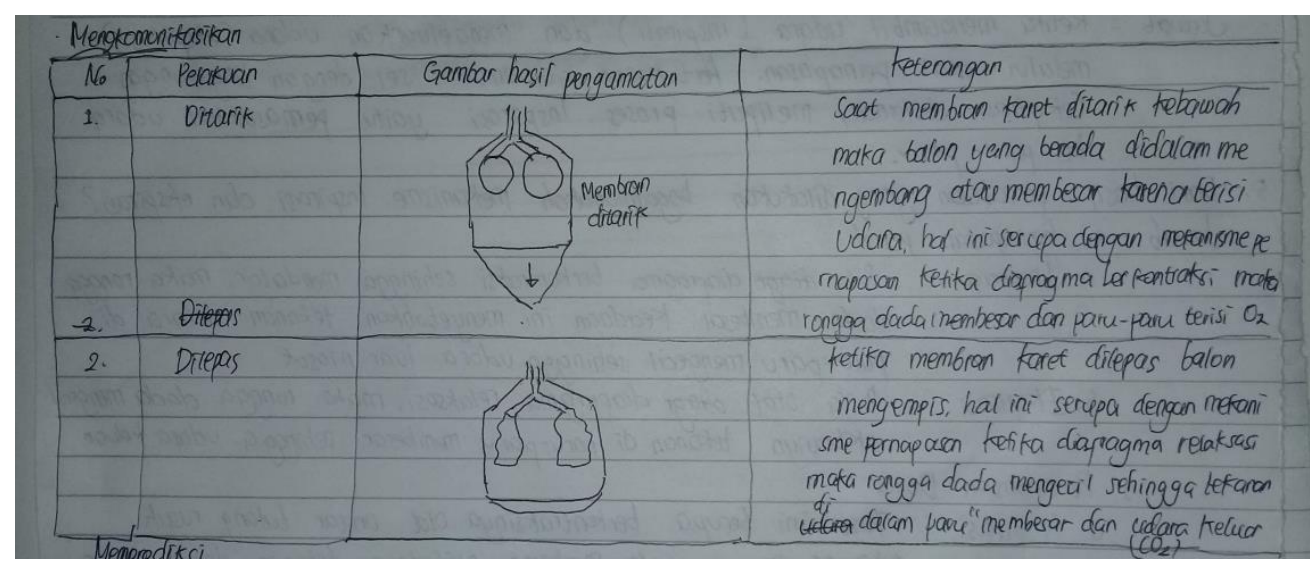

(a)

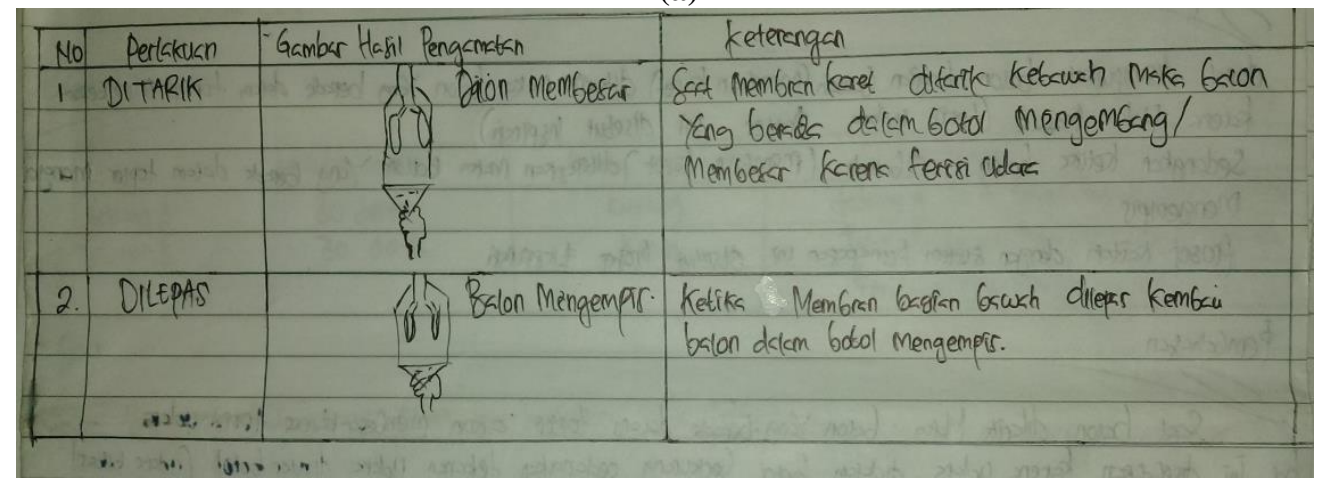

(b)

Gambar 5 Perbedaan Komunikasi kelas eksperimen dan kelas kontrol, (a) Komunikasi siswa pada kelas eksperimen dan (b) Komunikasi siswa pada kelas kontrol (Sumber: Dok, Pribadi 2017)

Keterampilan komunikasi meliputi keterampilan membaca grafik, tabel atau diagram. Setelah mengkomunikasikan hasil yang diperoleh pada kelompok masing-masing para siswa menghubungkan hasil-hasil pengamatan sehingga siswa dapat menarik kesimpulan, hal ini termasuk kedalam indikator interpretasi, dimana hasil yang diperoleh ditafsirkan sehingga mendapatkan sebuah kesimpulan. Menurut Hilpan (2014), menafsirkan (interpretasi) hasil pengamatan ialah menarik kesimpulan sementara dari data yang dicatatnya. Hasil-hasil pengamatan tidak akan berguna bila tidak ditafsirkan. Keterampilan interpretasi meliputi keterampilan mencatat hasil pengamatan, menghubungkan hasil pengamatan, dan menemukan pola keteraturan dari suatu segi pengamatan sehingga memperoleh sebuah kesimpulan.
Pada indikator interpretasi didapatkan hasil post-test yang diberikan pada kelas eksperimen dan kelas kontrol didapatkan hasil $66 \%$ pada kelas eksperimen dengan kategori baik dan $63 \%$ pada kelas kontrol dengan kategori baik. Kemudian dari hasil penilaian kinerja didapatkan $68 \%$ dengan kategori baik pada kelas eksperimen dan $61 \%$ dengan kategori cukup baik pada kelas kontrol. Dari hasil lembar kerja siswa dapat dilihat perbedaanya, dimana pada penilaian ini siswa diberikan beberapa pertanyaan yang berkaitan dengan indikator interpretasi, dari pertanyaan yang diberikan siswa kelas eksperimen menjawab pertanyaan dengan baik sedangkan pada kelas kontrol siswa menjawan dengan singkat. Hal ini dapat dilihat pada gambar berikut:

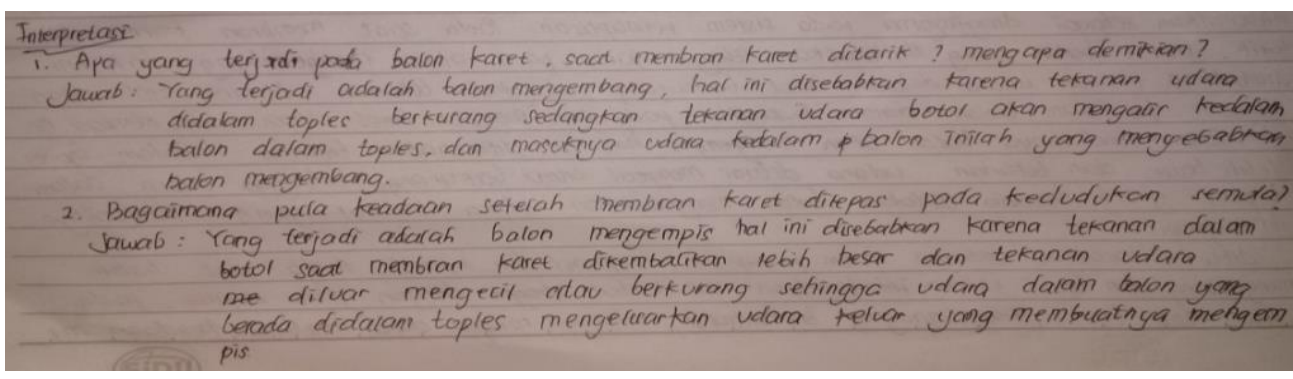




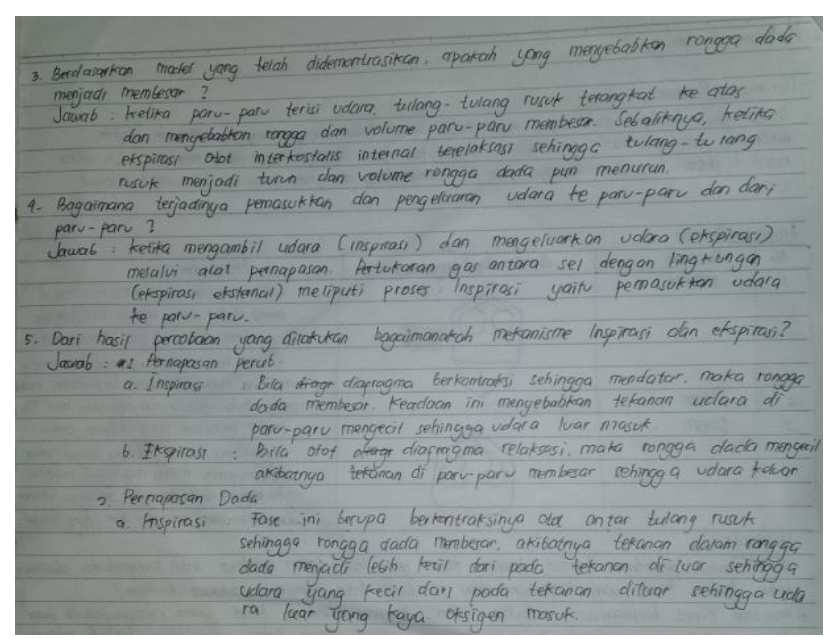

(a)

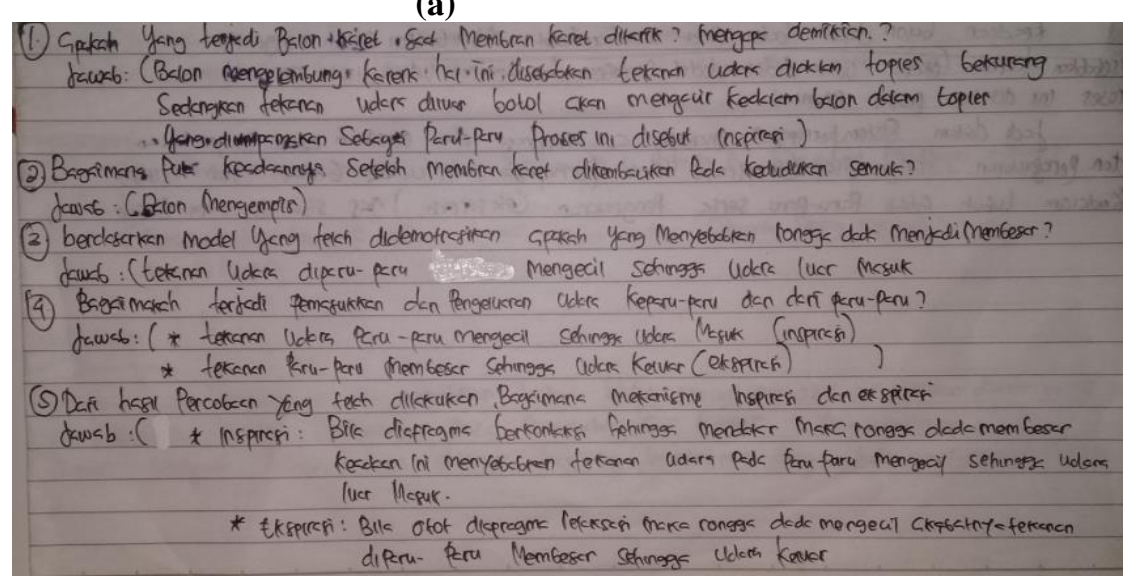

(b)

Gambar 4.6 Perbedaan Interpretasi kelas eksperimen dan kelas kontrol, (a) Interpretasi siswa pada kelas eksperimen dan (b) Interpretasi siswa pada kelas kontrol (Sumber: Dok, Pribadi 2017)

Menurut Hilpan (2014), keterampilan interpretasi meliputi keterampilan mencatat hasil pengamatan, menghubungkan hasil pengamatan, dan menemukan pola keteraturan dari suatu segi pengamatan sehingga memperoleh sebuah kesimpulan.

Dari hasil post-test yang diberikan pada kelas eksperimen dan kelas kontrol didapatkan hasil 69\% pada kelas eksperimen dengan kategori baik dan 59\% pada kelas kontrol dengan kategori baik. Kemudian dari hasil penilaian kinerja didapatkan $69 \%$ dengan kategori baik pada kelas eksperimen dan $61 \%$ dengan kategori cukup baik pada kelas kontrol. Dari hasil terseut diketahu terdapat perbedaan antara kesimpulan yang diperoleh siswa kelas eksperimen dan siswa kelas kontro, dimana siswa kelas eksperimen memperoleh kesimpulan yang berkaitan dengan pemahaman konsep, sedangkan siswa kelas kontrol hanya berkaitan dengan praktikum yang dilakukan, hal ini dapat dilihat dari gambar dibawah ini:

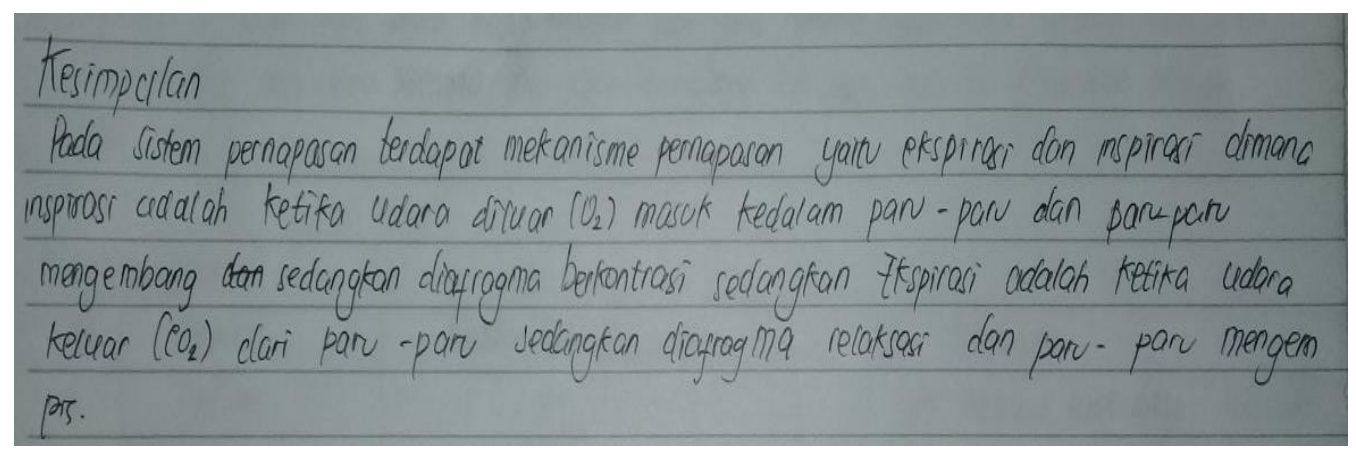

(a) 


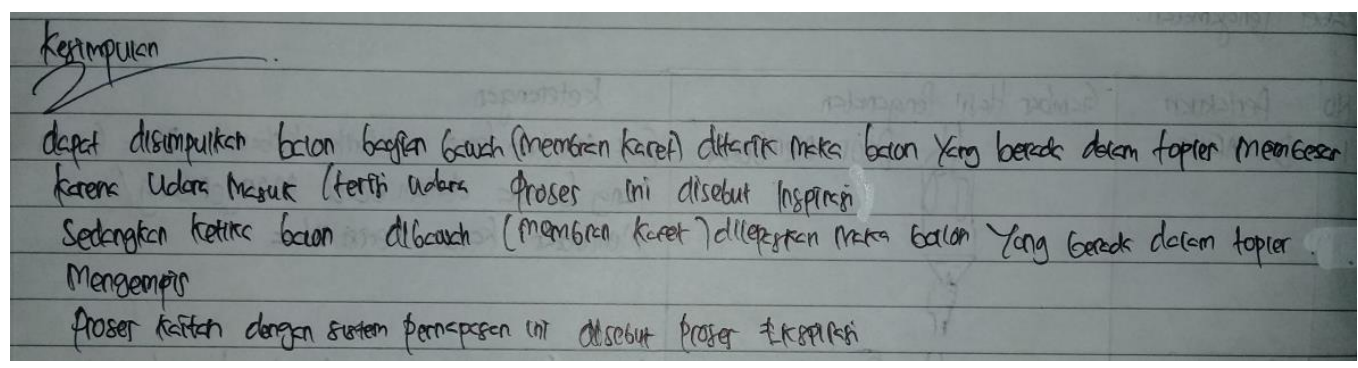

(b)

Gambar 7 Perbedaan Komunikasi kelas eksperimen dan kelas kontrol, (a) Komunikasi siswa pada kelas eksperimen dan (b) Komunikasi siswa pada kelas kontrol

(Sumber: Dok, Pribadi 2017)

Langkah yang ke lima adalah analisi dan evaluasi dari pemecahan masalah (analyze and evaluate the problem-solving process), siswa untuk melakukan analisis dan evaluasi dari pemecahan masalah. Pada tahapan ini guru mempersilahkan siswa untuk maju ke depan dan mempresentasikan hasil dari masingmasing kelompok, kemudian siswa dan guru bersama-sama melakukan analisis dan evaluasi dengan mengajukkan beberapa pertanyaan secara langsung kepada masing-masing kelompok. Menurut Arens (2012), Tahapan akhir problem based learning melibatkan kegiatan yang bertujuan untuk membantu siswa menganalisis dan mengevaluasi proses mereka sendiri serta keterampilan investigasi dan intelektual yang mereka gunakan.

Adanya perbedaan yang signifikan pada keterampilan proses sains antara kelompok siswa yang diterapkan dengan model pembelajaran problem based learning dan kelompok siswa yang diterapkan dengan model pembelajaran konvensional disebabkan oleh beberapa faktor, yaitu proses pembelajaran yang berorientasi terhadap masalah dan pengalaman belajar yang membuat siswa terjun langsung dalam peroses pembelajaran.

Dari data post-test menunjukkan keterampilan proses sains yang paling tinggi pada KPS komunikasi, menyusun hipotesis dan observasi. Keterampilan proses sains pada kelas eksperimen menunjukkan perbedaan yang signifikan antara sebelum dilaksanakannya kegiatan pembelajaran dan setelah dilaksanakannya kegiatan pembelajaran yang menggunakan model problem based learning, dengan menggunakan model pembelajaran ini siswa diberikan suatu permasalahan yang harus siswa pecahkan bersama-sama hal ini menuntut siswa untuk berfikir tingkat tinggi dan perperan aktif dalam proses pembelajaran, sehingga siswa dapat terjut langsung dalam kegiatan pembelajaran hal inilah yang menyebabkan meningkatnya ketrampilan proses sains pada kelas eksperimen yang mana siswa terjun langsung untuk aktif memecahakan masalah dengan berbagai sumber dan melakukan percobaan secara langsung berkaitan dengan masalah yang diberikan pada proses pembelajaran dibandingkan dengan kelas kontrol yang menggunakan model pembelajaran konvensional, menurut Novita $d k k$ (2014), model pembelajaran problem based learning memiliki karatkteristik, yaitu penyelidikan autentik. Problem based learning mengaharuskan siswa melakukan penyelidikan autentik yang meliputi menganalisis dan mendefinisikan masalah, membuat hipotesis, mengumpulkan dan menganalisis informasi, melakukan percobaan, dan merumuskan kesimpulan, semua kegiatan tersebut mengharuskan siswa untuk berperan aktif dalam proses pembelajaran dan melatih keterampilan proses mereka.

Perbedaan yang signifikan ini juga dapat dilihat dari hasil penilaian kinerja yang dilakukan pada saat siswa melakukan kegiatan pembelajaran, dari hasil penilaian kinerja kelas eksperimen memiliki kategori yang baik pada setiap indikatornya sedangkan kelas kontrol memiliki kategori yang cukup baik sampai dengan kategori baik. Hal ini dikarenakan siswa pada kelas eksperimen memiliki pengalaman langsung dalam kegiatan pembelajaran dengan melakukan kegiatan praktikum, dengan berperan aktif untuk menyelesaikan permasalahan yang diberikan oleh guru sehingga indikator-indikator keterampilan proses sains terpenuhi berbeda dengan kelas kontrol yang hanya memperhatikan guru dalam proses pembelajaran tanpa memiliki pengalaman langsung dan siswa tidak berperan aktif dalam kegiatan pembelajaran. Menurut Wahyudi (2015), dalam memecahkan masalah, problem based learning lebih mengutamakan keaktifan siswa karena kegiatan dalam problem based learning meliputi pengamatan terhadap masalah, perumuskan terhadap hipotesis, perencanakan penelitian sampai pelaksanaannya, hingga mendapatkan sebuah kesimpulan dari jawaban atas permasalahan yang diberikan.

Hasil penelitian ini didukung oleh beberapa penelitian relevan yang telah dilakukan sebelumnya 
berkaitan dengan model pembelajaran problem based learning. Penelitian ini menggunakan model pembelajaran problem based learning sebelumnya telah dilakukan oleh Rusnayati dan Prima (2011), berdasarkan hasil dari perbandingan peningkatan keterampilan proses sains menunjukkan bahwa kelas eksperimen mengalami peningkatan keterampilan proses sains yang lebih tinggi dibandingkan dengan kelas kontrol. Kelas eksperimen mengalami peningkatan keterampilan proses sains dengan kategori tinggi $(\langle\mathrm{g}\rangle=0,87)$ lebih tinggi peningkatannya dibandingkan dengan kelas kontrol yang hanya mengalami peningkatan keterampilan proses sains dengan kategori baik $(\langle\mathrm{g}\rangle=0,59)$. Berdasarkan hasil tersebut dapat dinyatakan bahwa keterampilan proses sains dapat meningktkan keterampilan proses sains pada siswa.

Penelitian lainnya yang dilakukan oleh Wahudi (2015), Hasil analisis statistik menunjukkan bahwa model pembelajaran problem based learning berpengaruh terhadap keterampilan proses sains dan hasil belajar biologi pada ranah pengetahuan, namun tidak berpengaruh terhadap ranah sikap. Pernyataan tersebut juga didukung secara deskriptif yaitu pada kelas eksperimen nilai rata-rata hasil belajar ranah pengetahuan 76,09 , rata-rata keterampilan proses sains 76,97 dan rata-rata hasil belajar sikap 76,09. Hasil belajar kelas kontrol pada ranah pengetahuan memiliki rata-rata 68,12 , rata-rata ranah keterampilan proses sains 69,37 dan rata-rata hasil belajar pada ranah sikap adalah 75,00. Perbedaan rata-rata hasil belajar pada ranah pengetahuan, dan keterampilan proses sains kelompok eksperimen yang menggunakan model problem based learning menunjukkan hasil yang lebih tinggi dibandingkan dengan kelompok kontrol yang menggunakan pembelajaran konvensional, namun untuk hasil belajar ranah sikap antara kelompok eksperimen dan kontrol tidak menunjukkan perbedaan secara signifikan.

Penelitian lainnya dilakukan oleh Novita $d k k$ (2014), berdasarkan analisis perhitungan, rerata hasil tes keterampilan proses sais siswa yang mengikuti pembelajaran menggunakan model pembelajaran problem based learning lebih tinggi $(=21,44)$ dibandingkan dengan rerata hasil tes keterampilan proses sains siswa yang mengikuti pembelajaran menggunakan model konvensional $(=13,04)$. Berdasarkan hasil tersebut dapat dinyatakan bahwa keterampilan proses sains dapat meningktkan keterampilan proses sains pada siswa.
Berdasarkan penjelasan di atas, dapat diketahui bahwa terdapat perbedaan keterampilan proses sains antara kelas eksperimen yang menggunakan model pembelajaran problem based learning dan kelas kontrol yang menggunakan model konvensional. Adanya perbedaan tersebut menunjukkan bahwa model pembelajaran problem based learning (PBL) berpengaruh terhadap keterampilan proses sains.

\section{KESIMPULAN}

Berdasarkan hasil penelitian, dapat disimpulkan bahwa model pembelajaran problem based learning memiliki pengaruh terhadapa keterampilan proses sains siswa pada materi sistem pernapasan. Hasil uji hipotesis pada paired sampel t-test pada kelas eksperimen menunjukan nilai signifikansi lebih kecil dari 0,05 sehingga Ho ditolak dan artinya terdapat perbedaan keterampilan proses sains antara sebelum kegiatan pembelajaran dan setelah kegiatan pembelajaran, sedangkan pada kelas kontrol nilai signifikansi 0,122 lebih besar dari 0,05 yang artinya tidak terdapat perbedaan ketermapilan proses sains antara sebelum dan sesudah, sedangkan pada independen sampel t-test nilai signifikasnsi $(0,044<0,05)$ yang artinya terdapat perbedaan keterampilan proses sains pada kelas eksperimen dan kontrol.

\section{DAFTAR PUSTAKA}

[1] Ali. L.U., Suastra. I.W., dan Sudiatmika . A. A. I. A. R. 2013. Pengelolaan Pembelajaran IPA Ditinjau dari Hakikat Sains Pada SMP Di Kabupaten Lombok Timur. Vol 3 Tahun 2013. Diakses pada Sabtu 01 Oktober 2016 pukul 19.51 WIB

[2] Arends. R.I. 2012. Learning To Teach, Ninth Edition. New York: The McGraw-Hill campanies

[3] Hilpan, M. 2014. Analisis Ketersediaan Keterampilan Proses Sains (KPS) dalam Buku Sekolah Elektronik (BSE) Fisika Kelas XI Pada Konsep Fluida.Skripsi. Jakarta: UIN Syarif Hidayatullah Press

[4]Munir. 2010. Metode Yasiniyah Sebagai Metode Pembelajaran Membaca Al-Qur'an. Vol. XV No. 01. Diakses pada Sabtu 24 Desember 2016 pukul 20.35 WIB

[5] Novita, D.L,. Sudana. D.N,. dan Riastini.P.N,. 2014. Pengaruh Model Pembelajaran PBL Terhadap Keterampilan Proses Sains Siswa kelas V SD di Gugus IV Diponegoro Kecamatan Mendoyo. Vol.2 No.1 Tahun 2014 ISSN 1336- 
7775. Diakses pada 17 September 2016 pukul 21.15 WIB

[6] Novitasari. 2012. Pengaruh Metode Student Created Case Studies Disertai Media Gambar Terhadap Keterampilan Proses Sains Siswa Kelas X SMA Negeri 1 Mojolaban Sukoharjo. Surakarta: Universitas Sebelas Maret

[7] Rusnayati. H dan Prima. E.C. 2011. Penerapan Model Pembelajaran Problem Based Learning Dengan Pendekatan Inkuiri Untuk Meningkatkan Keterampilan Proses Sains Dan Penguasaan Konsep Elastisitas Pada Siswa
SMA. Vol. 15 No. 147 Tahun 2011 ISSN. Diakses pada 03 Oktober 2016 pukul 14.21 WIB

[8] Sani.R.A. 2014. Pembelajaran Saintifik Untuk Imlementasi Kurikulum 2013.Jakarta Bumi Aksara

[9] Wahyudi.A,. Marjono,. dan Herlita. 2015. Pengaruh Problem Based Learning Terhadap Keterampilan Proses Sains Dan Hasil Belajar Biologi Siswa Kelas X SMA Negeri Jumapolo Tahun Pelajaran 2013/2014.Vol. 4 No. 1. ISSN 2252-6897 Tahun 2015. Diakses pada 03 Oktober 2016 pukul 14.05 WIB 